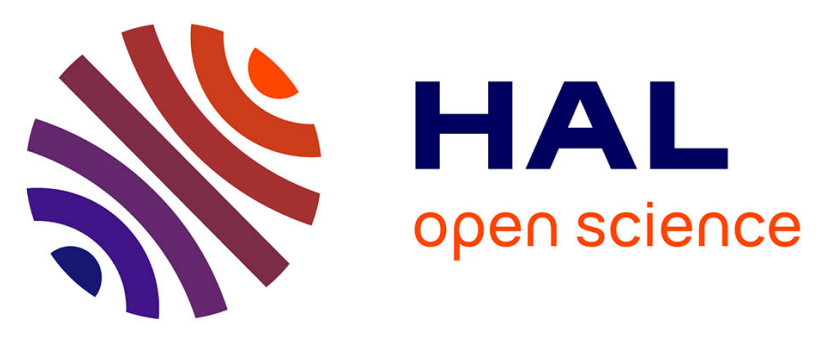

\title{
CAMELS-FR: A large sample, hydroclimatic dataset for France, to support model testing and evaluation
}

\author{
Vazken Andréassian, Olivier Delaigue, Charles Perrin, Bruno Janet, Nans
}

Addor

\section{- To cite this version:}

Vazken Andréassian, Olivier Delaigue, Charles Perrin, Bruno Janet, Nans Addor. CAMELS-FR: A large sample, hydroclimatic dataset for France, to support model testing and evaluation. EGU General Assembly 2021, Apr 2021, Vienna, Austria. 10.5194/egusphere-egu21-13349 . hal-03370674

\section{HAL Id: hal-03370674 \\ https://hal.inrae.fr/hal-03370674}

Submitted on 8 Oct 2021

HAL is a multi-disciplinary open access archive for the deposit and dissemination of scientific research documents, whether they are published or not. The documents may come from teaching and research institutions in France or abroad, or from public or private research centers.
L'archive ouverte pluridisciplinaire HAL, est destinée au dépôt et à la diffusion de documents scientifiques de niveau recherche, publiés ou non, émanant des établissements d'enseignement et de recherche français ou étrangers, des laboratoires publics ou privés. 


\section{EGU}

\section{$>$ CAMELS-FR}

\section{A large sample hydroclimatic dataset for France to support model testing and evaluation}

Vazken Andréassian ${ }^{1}$, Olivier Delaigue ${ }^{1}$, Charles Perrin ${ }^{1}$, Bruno Janet ${ }^{2} \&$ Nans Addor $^{3}$

1. Université Paris-Saclay, INRAE, UR HYCAR, Antony, France

2. SCHAPI, Toulouse, France

3. University of Exeter, Exeter, UK

olivier.delaigue@inrae.fr

webgr.inrae.fr

\section{INRAC universıte் PARIS-SACLAY \\ V'GICRUES EXXETER}




\section{Context}

\section{Large sample hydrology}

- Over the last decades, development of large sample hydrology (Andréassian et al., 2006; Gupta et al. 2014)

- Generalization of sound model evaluation and testing practices based on various types of split-sample tests

- CAMELS international initiative (Addor et al., 2017): facilitate reproducible hydrological research by the use of large sample catchment datasets

Several CAMELS datasets already published:

- USA

- Chili

- Great-Britain

Other datasets are being finalized:

- Australia

- France

Andréassian, V., Hall, A. Chahinian, N., Schaake, J. (2006). Introduction and Synthesis: Why should hydrologists work on a large number of basin data sets? IAHS Publication, $307,1-5$, https://hal.inrae.fr/hal-02588687. Gupta, H.V., Perrin, C., Blöschl, G., Montanari, A., Kumar, R., Clark, M., Andréassian, V. (2014). Large-sample hydrology: A need to balance depth with breadth. Hydrology and Earth System Sciences, 18(2), 463-477, do: https://doi.org/10.5194/hess-18-463-2 


\section{Context}

\section{Large sample hydrology expertise at INRAE (France)}

Increasing number of studies conducted on large datasets over the last three decades

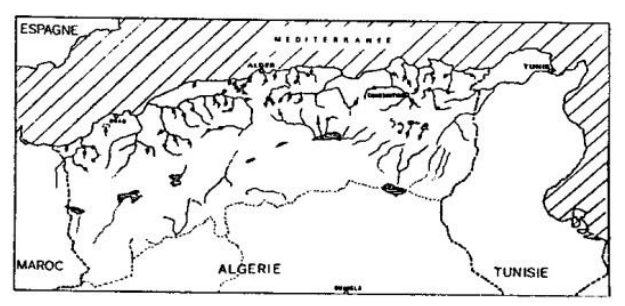

63 catchments in Algeria (Kabouya et al., 1991)

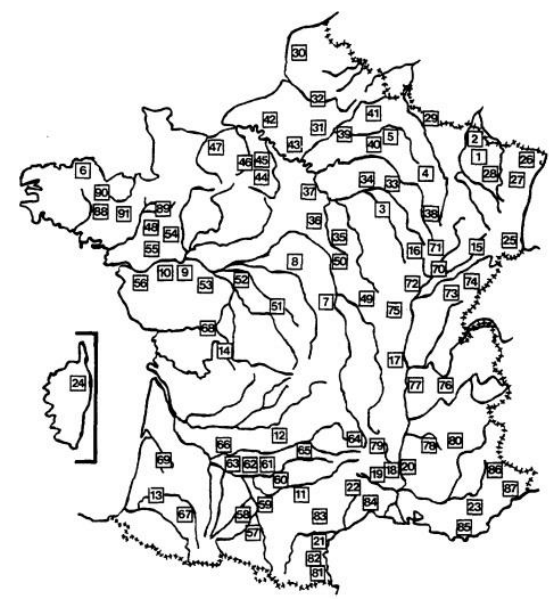

91 catchments in France (Makhlouf et al., 1994)

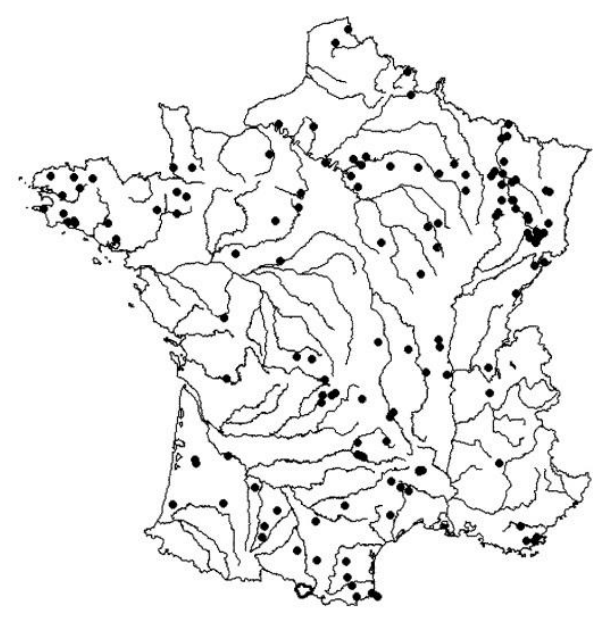

140 catchments in France (Edijatno et al., 1999)

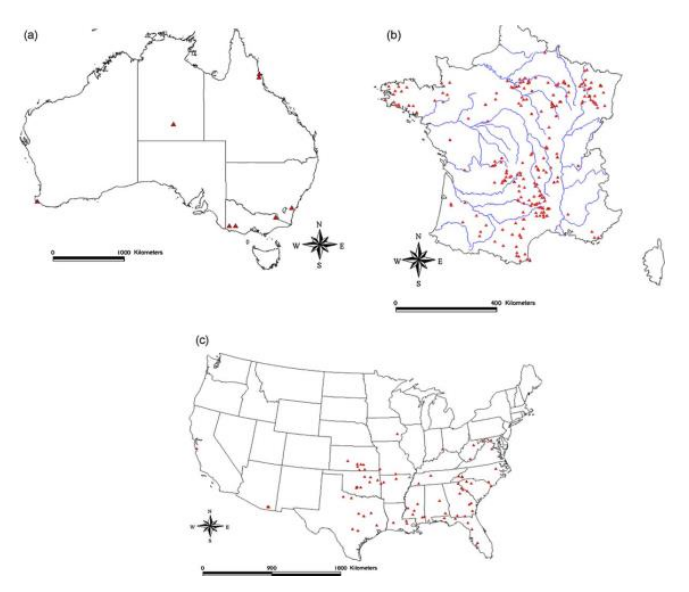

308 catchments in Australia, France \& USA (Oudin et al., 2005) 


\section{Context}

\section{Hydrological tourism?}

According to the United Nations (UNWTO agency):

France is on the top of the world tourism rankings not only because of the beauty of Paris

or the Mont-Saint-Michel or because of the quality of wines but also because of the diversity of the landscapes

Indeed, France is a very diverse territory:

- climates

- soils

- relief

- etc.

An ideal playground for hydrologists!
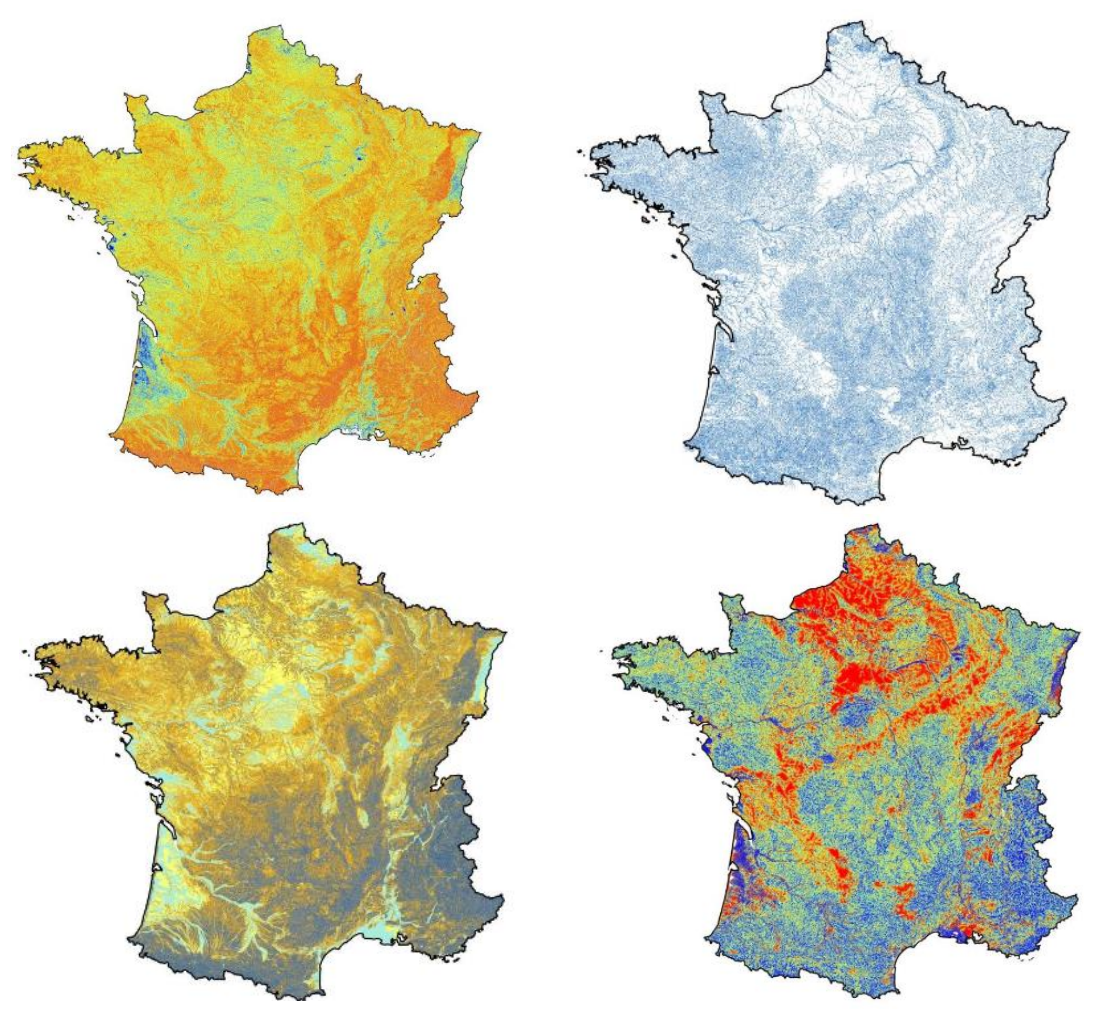


\section{The CAMELS-FR dataset}

\section{Data sources}

Dataset assembled by an automated chain fed by national data products (Delaigue et al., 2020)

CAMELS-FR dataset on several hundreds of watersheds over the 1958-2021 period:

- Hydrological data (from French national Banque hydro)

- Streamflow time series

- Qualitative indices time series

- Information about possible regulations upstream

- Climatic data (from Météo-France SAFRAN product)

- Solid and liquid precipitation time series

- Potential evapotranspiration time series

- Temperature time series

- Other time series

- Land cover (from Corinne Land Cover)

- Topography indices (from the SRTM DEM)

- Elevation and slope distributions

- Drainage density

- Topographic index

- etc. 


\section{The CAMELS-FR dataset}

\section{Hydrological data}

- More than 4000 hydrological stations in Banque Hydro

- Station snapped on INRAE theoretical hydrographic network

- Catchments automatically computed by INRAE and checked visually
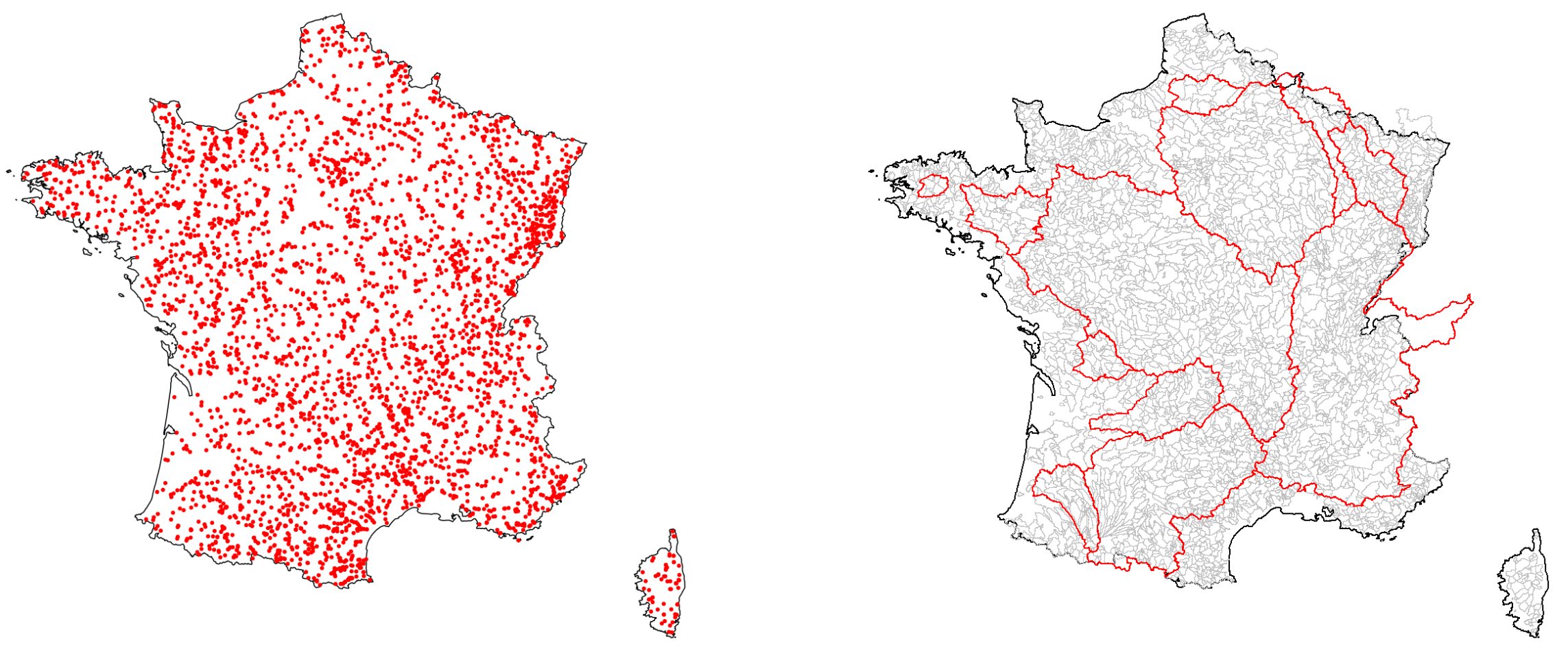


\section{The CAMELS-FR dataset}

\section{Climatic data}

SAFRAN atmospheric reanalysis produced provided by Météo-France at daily time step (Vidal et al., 2010)

- Mesoscale analysis system of near-surface atmospheric variables

- Use of ground observations, combined with data from meteorological models

Parameters interpolated on a regular grid $\left(8 \times 8 \mathrm{~km}^{2}\right)$ :

- solid and liquid precipitation

- temperature

- potential evaporation

- humidity

- wind

- water equivalent of snow

METEO

- solar radiation

- infrared radiation

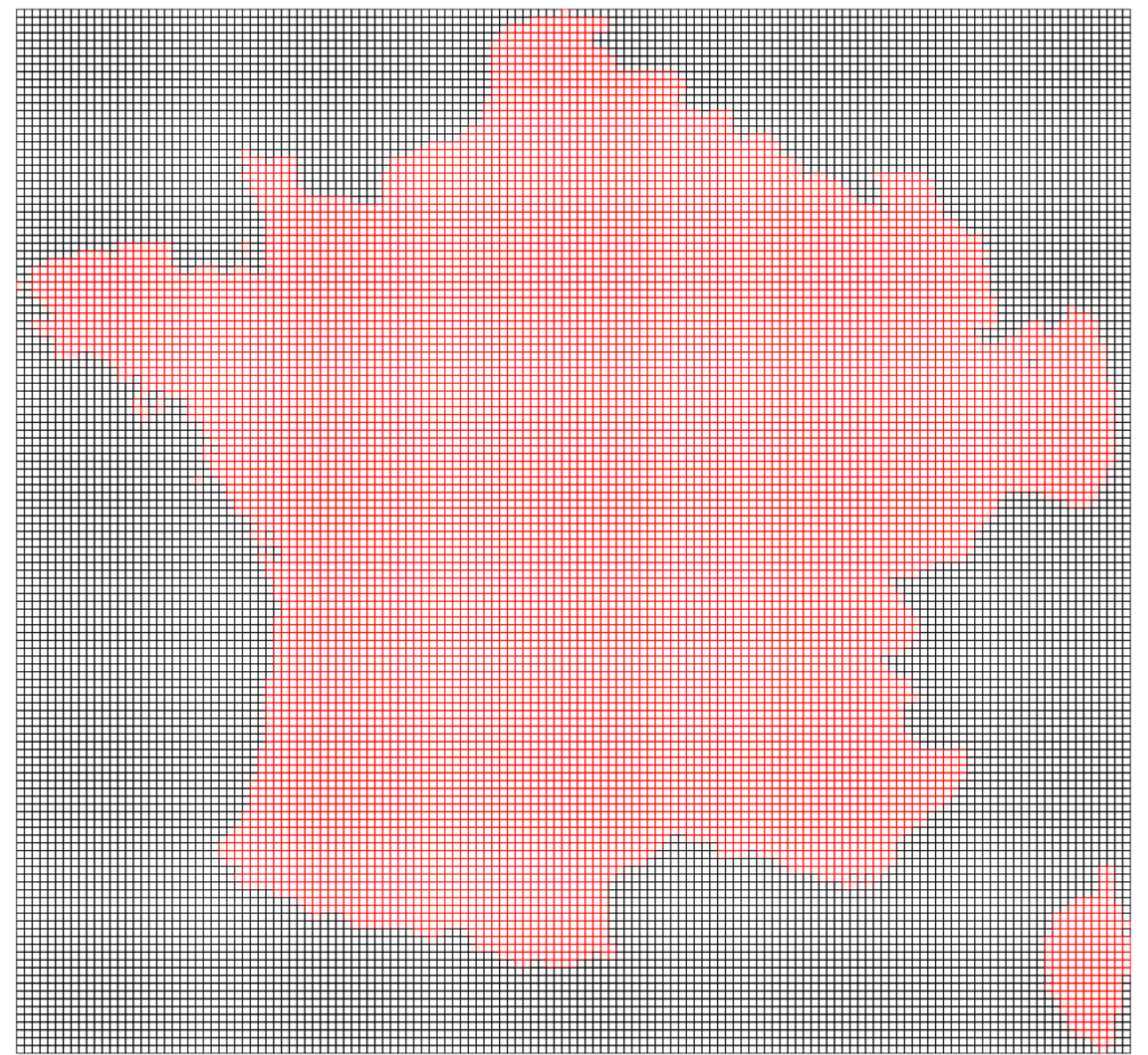

Vidal, J. P., E. Martin, L. Franchisteguy, F. Habets, J. M. Soubeyroux, M. Blanchard and M. Baillon (2010). "Multilevel and multiscale drought reanalysis over France with the Safran-Isba-Modcou hydrometeorological 


\section{The CAMELS-FR dataset}

\section{EGU}

\section{Examples of variables}

Precipitation (mm)

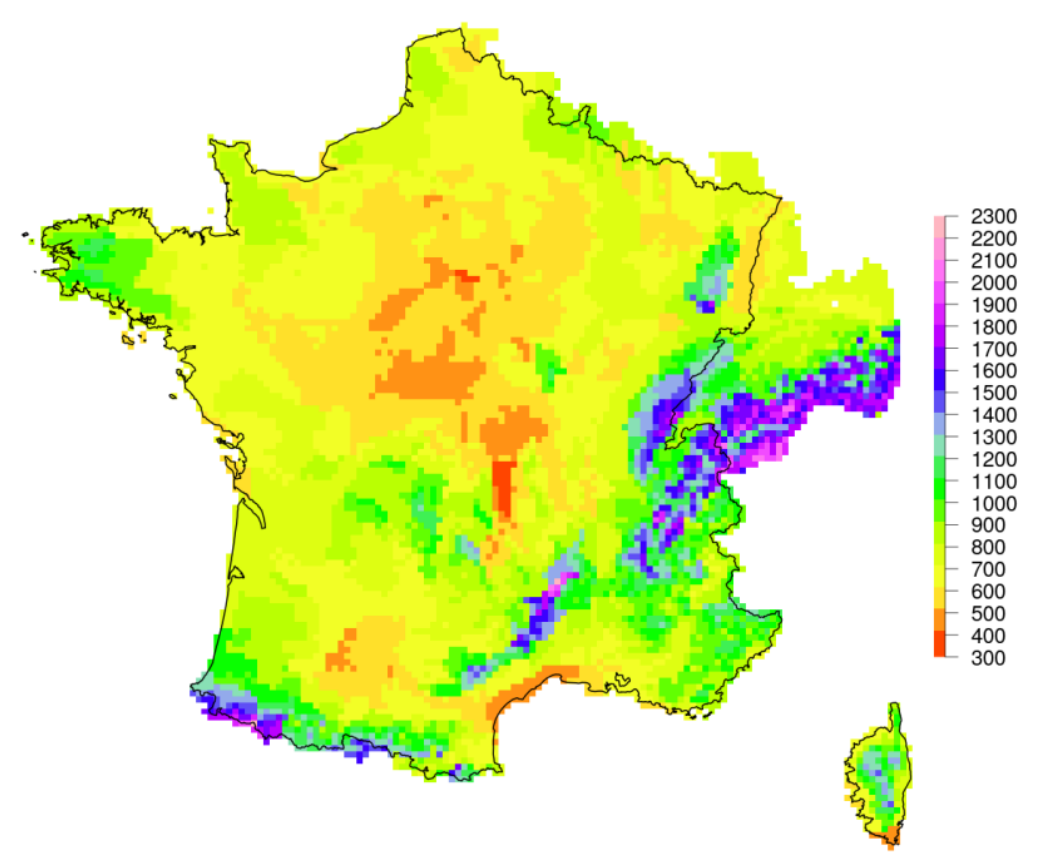

Solid precip. fraction (\%)

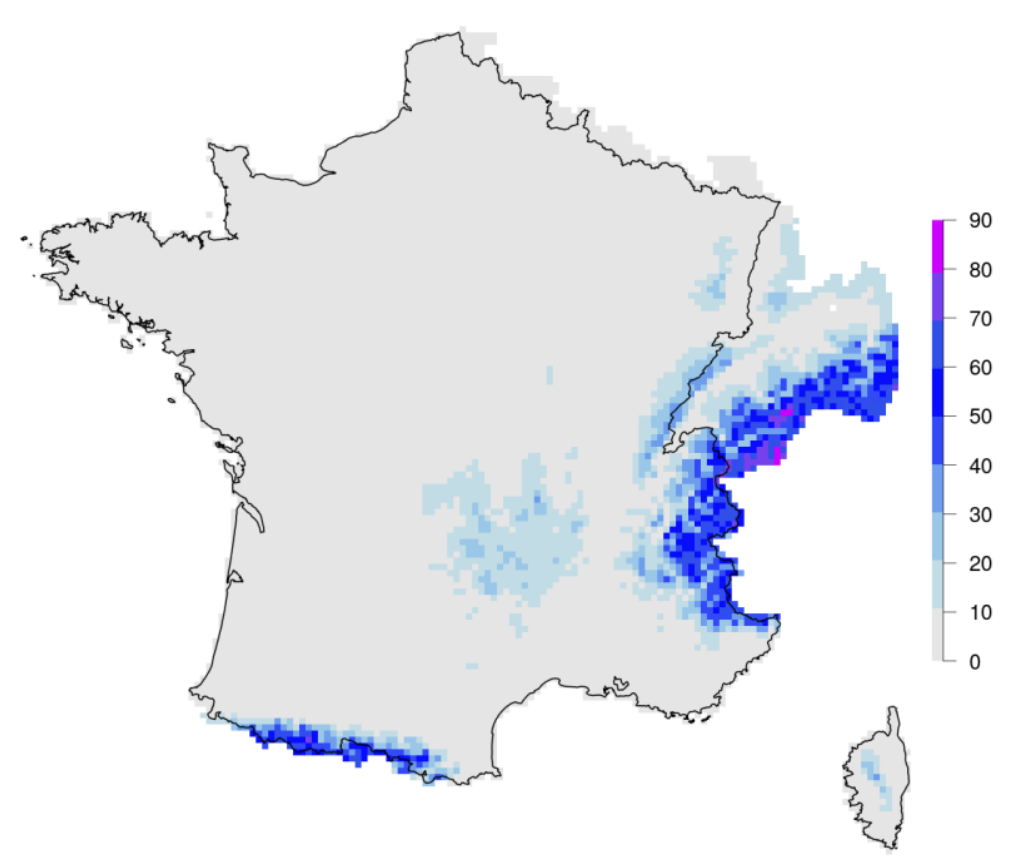

Evapotranspiration (mm)

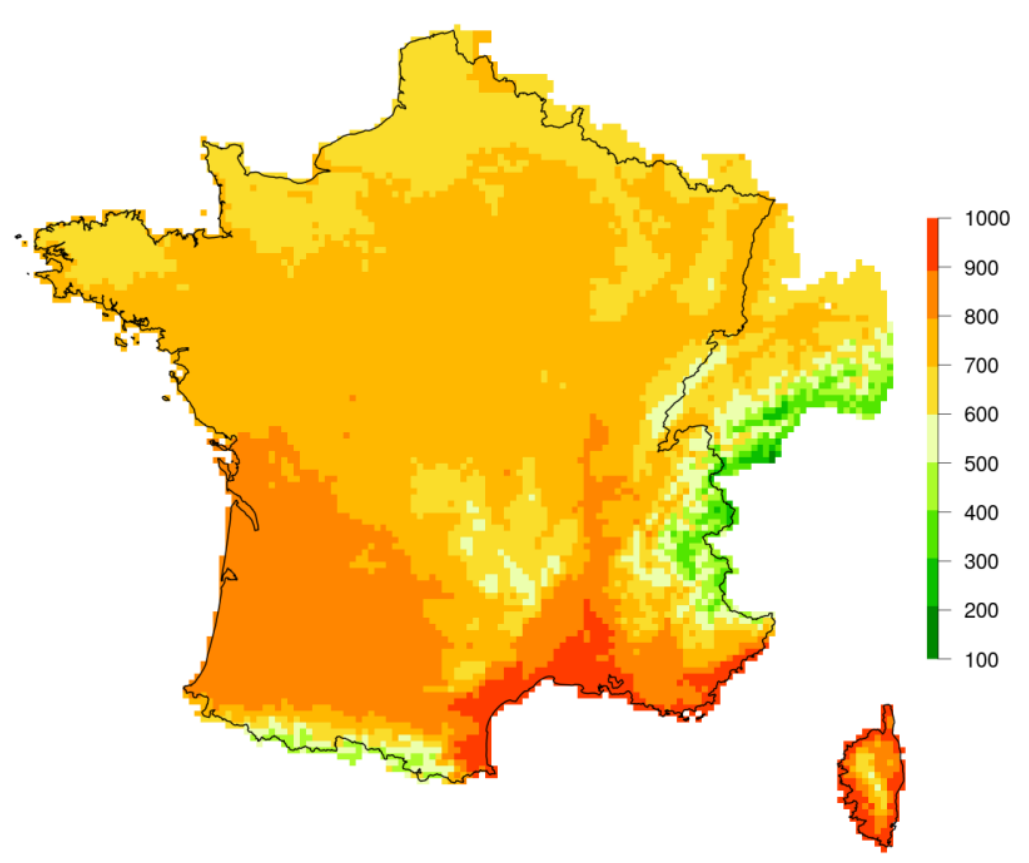




\section{The CAMELS-FR dataset}

\section{EGU}

\section{Examples of variables}

Base flow index

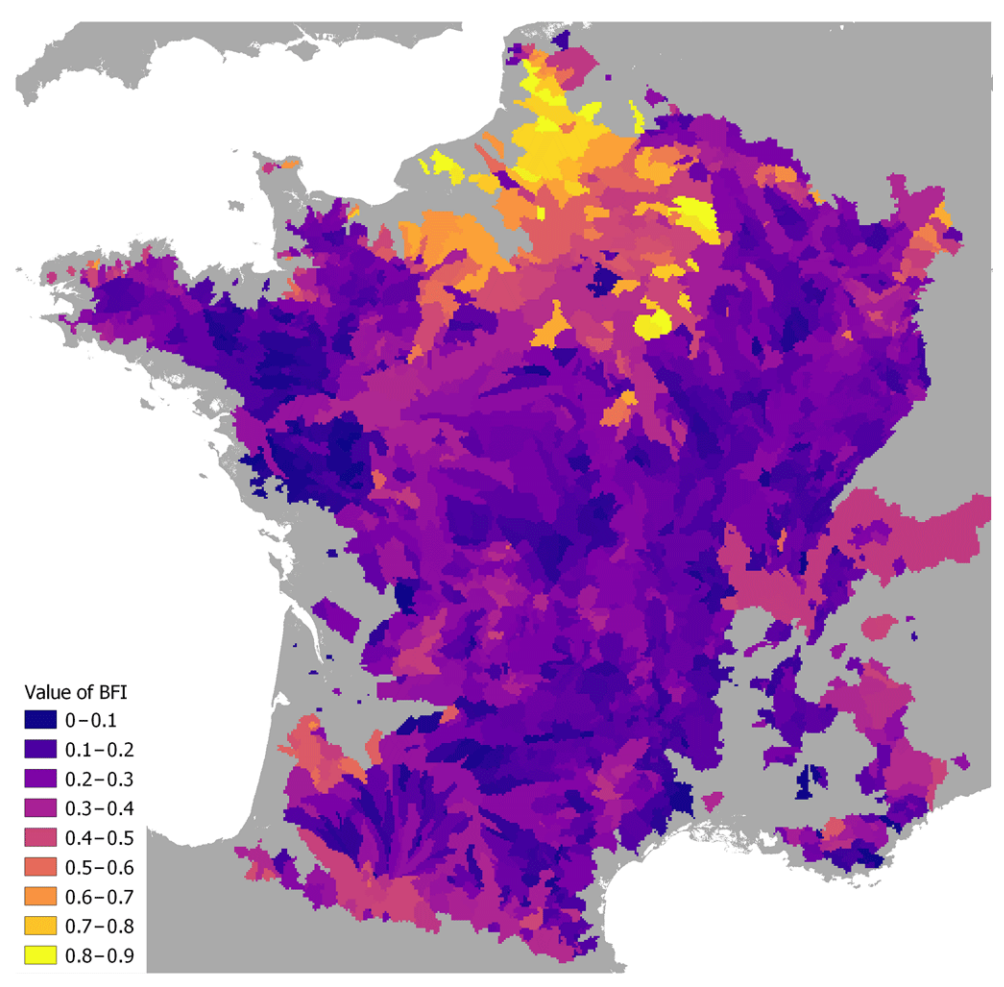

Land cover

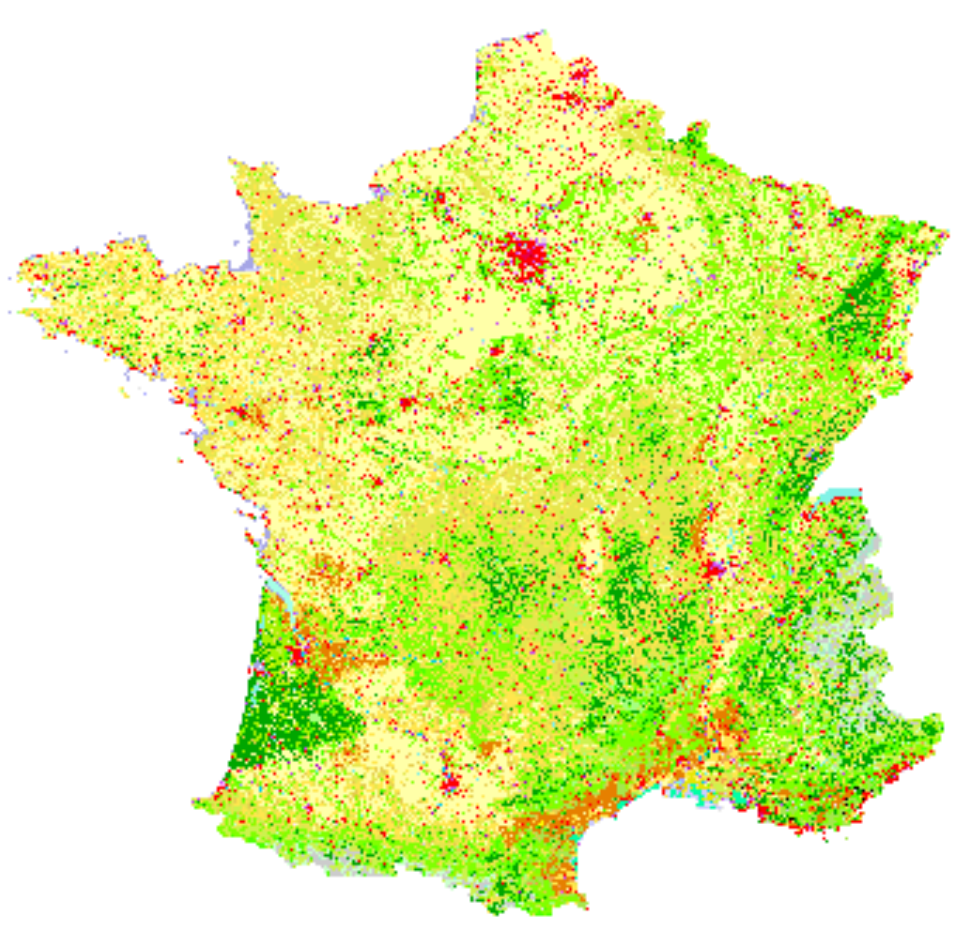




\section{The CAMELS-FR dataset}

\section{Examples of variables}

\section{Elevation (m)}

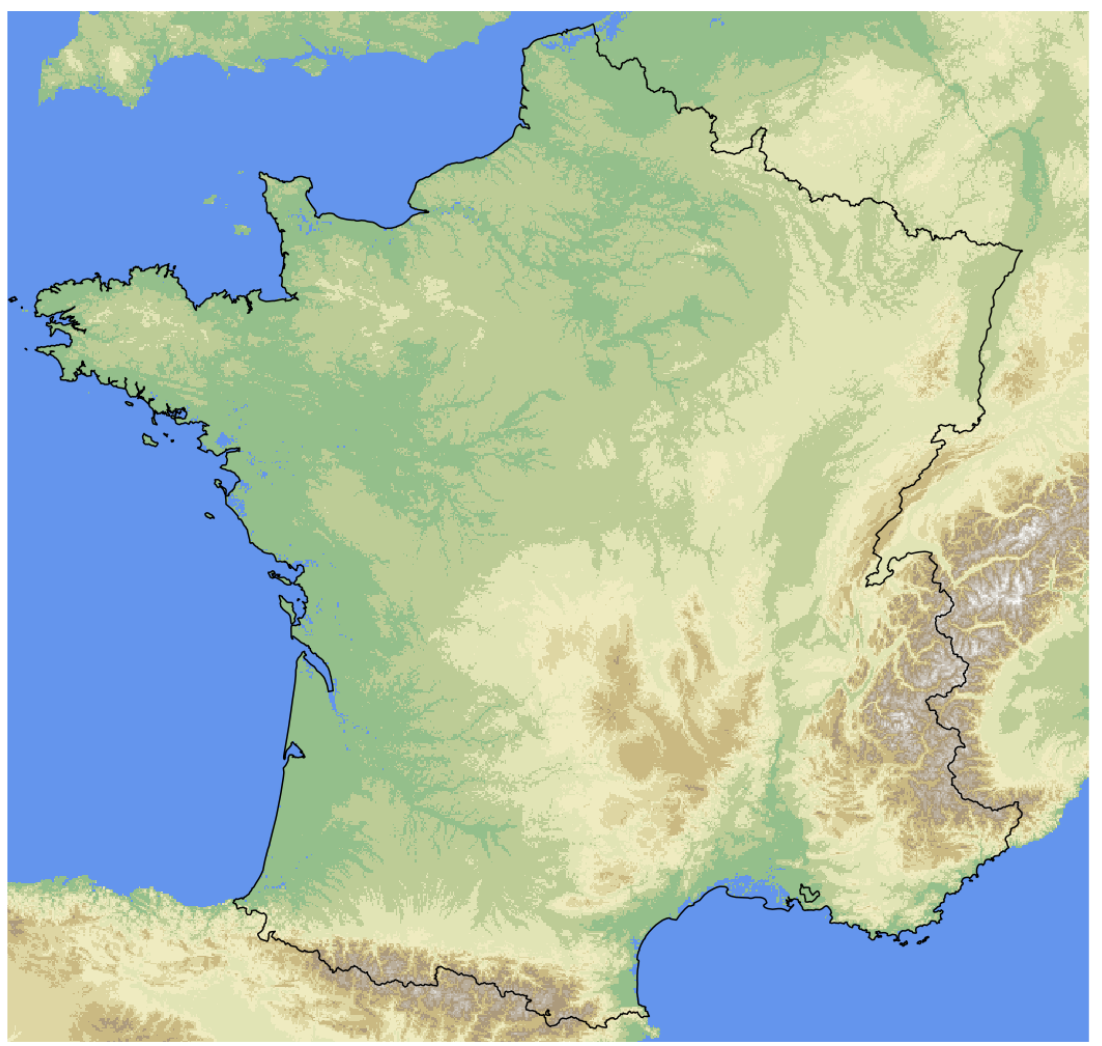

Geology

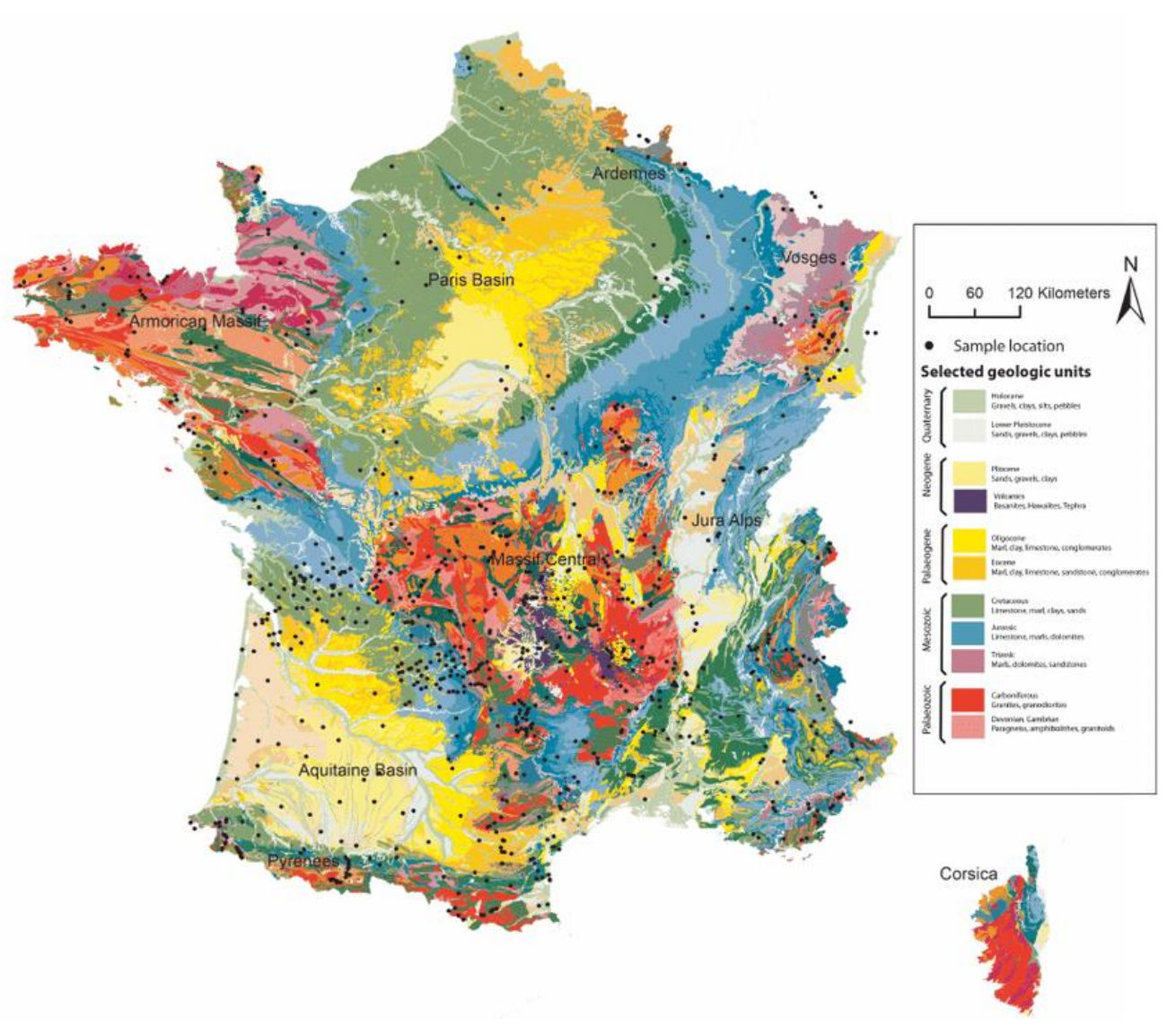




\section{The CAMELS-FR dataset}

\section{Example of time series}

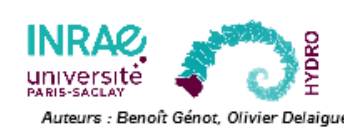

\section{L'Ardèche à Vogüé}

Station : V5014010 Superficie : $619.87\left[\mathrm{~km}^{2}\right]$

$X=765013[\mathrm{~m}] ; Y=765013[\mathrm{~m}]$ (Lambert 2 étendu) $; Z=181[\mathrm{~m}]$
Gestionnaire : SPC Grand Delta
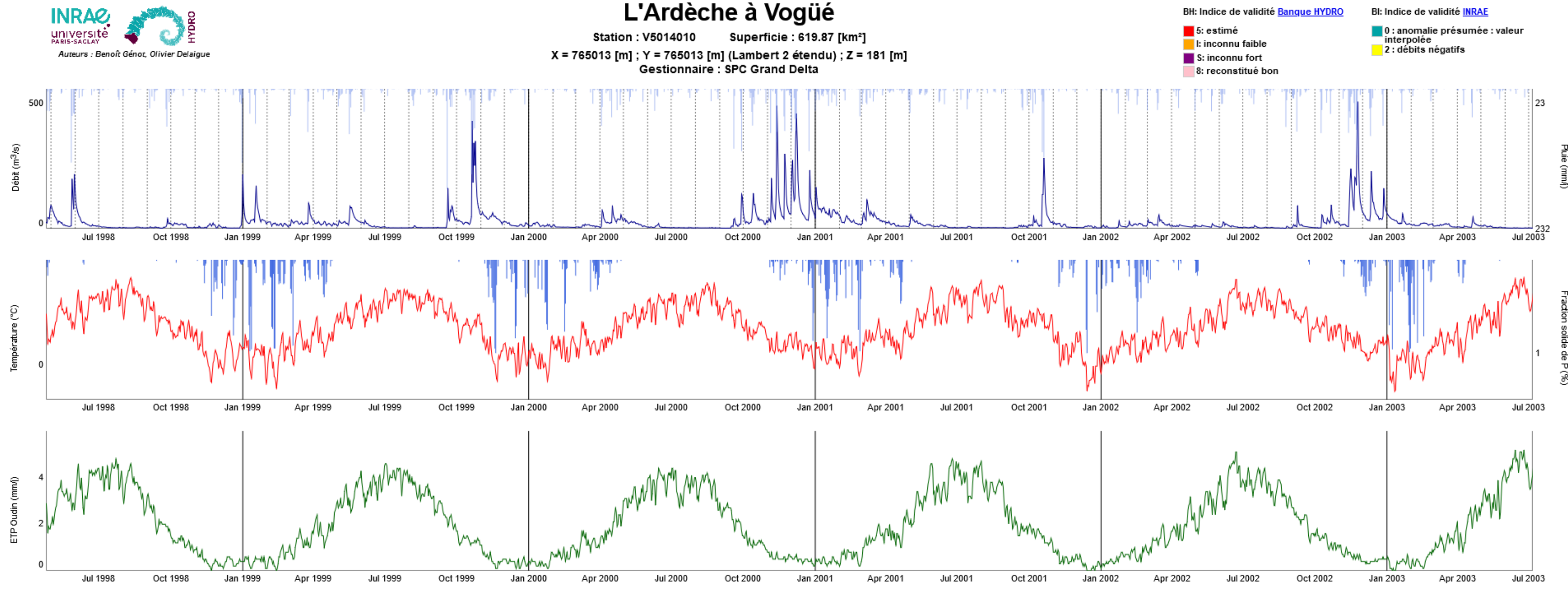


\section{The CAMELS-FR dataset}

\section{Example of time series}

INRAR

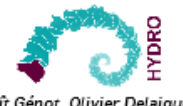

Le Petit Thérain à Saint-Omer-en-Chaussée

Station : $\mathrm{H7713010}$ Superficie : $214.11\left[\mathrm{~km}^{2}\right]$

Station $: \mathrm{H} 7713010 \quad$ Superficie $: 214.11\left[\mathrm{~km}^{2}\right]$
$\mathrm{X}=575513[\mathrm{~m}] ; \mathrm{Y}=575513[\mathrm{~m}]($ Lambert 2 étendu) $\mathrm{Z}=\mathbf{Z}=89 \mathrm{~m}]$
Gestionnaire $:$ DREAL Picardie

BH: Indice de validité Banque HYORO Bi: Indice de validité INRAE

I: estimé

1: inconnu faible
S: inconnu fort
8: reconstitue bon

[no 0 : anomalie présumée : vale

(a)
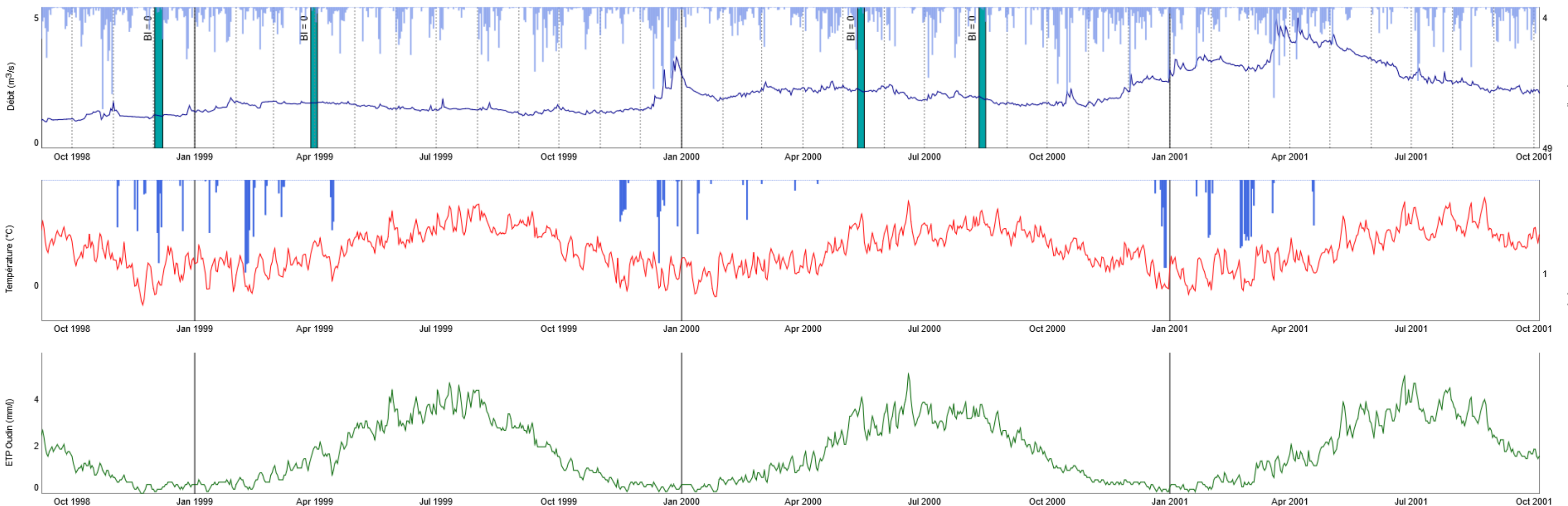


\section{The CAMELS-FR dataset}

Example graphical summary sheet on CAMELS-FR catchments

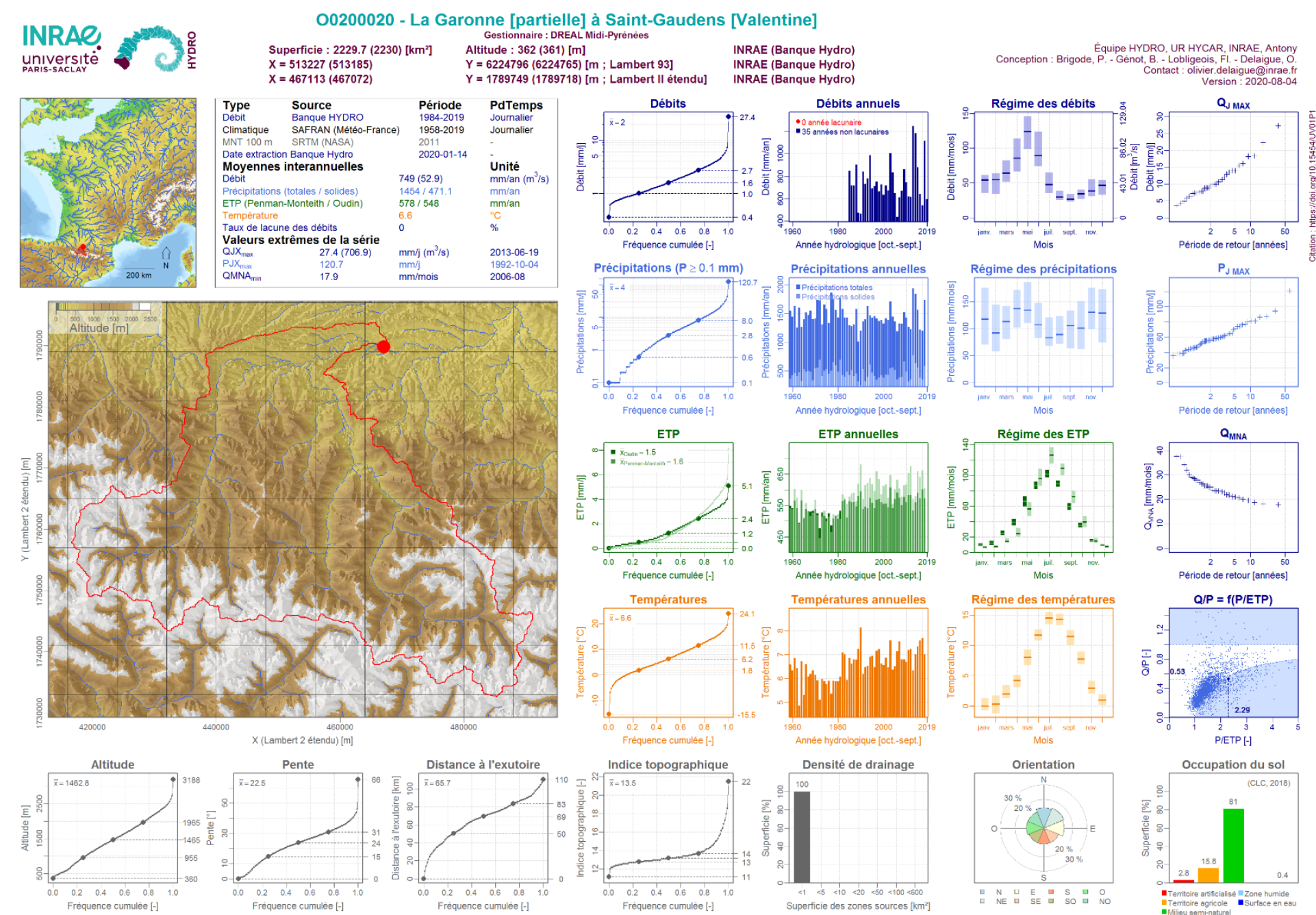




\section{The CAMELS-FR dataset}

A graphical user interface to help users to select catchments

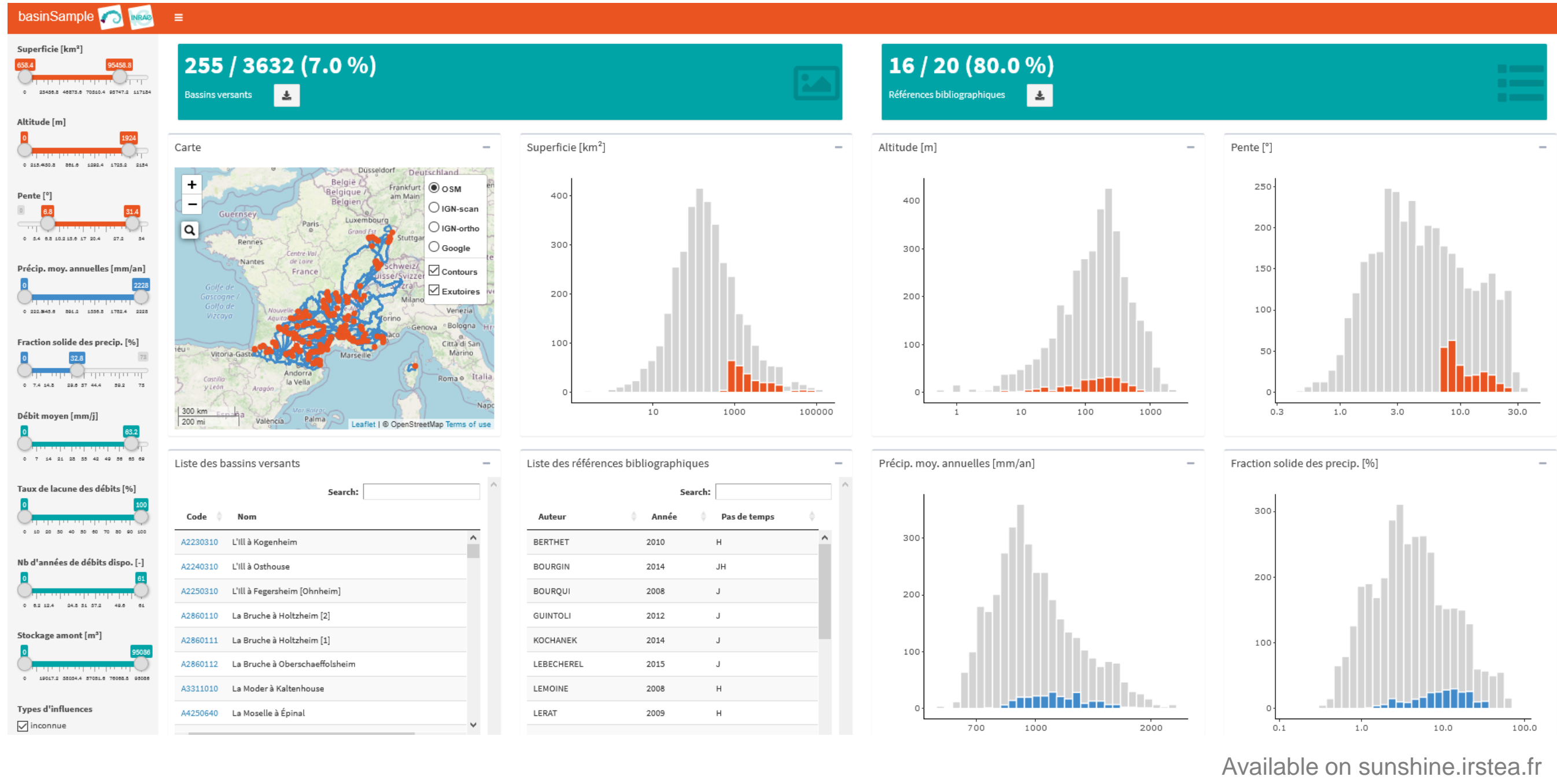




\section{The CAMELS-FR dataset}

How to retrieve the data?

The CAMELS-FR dataset will be available in the second half of 2021 on the following websites:

- The HYMEX web portal

- https://www.hymex.org/

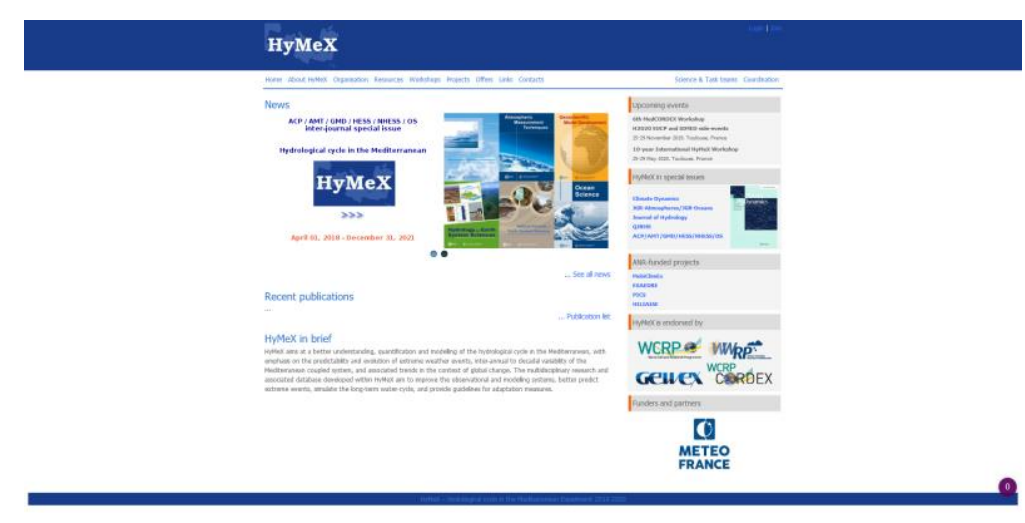

- The webGR webiste

- https://webgr.inrae.fr/

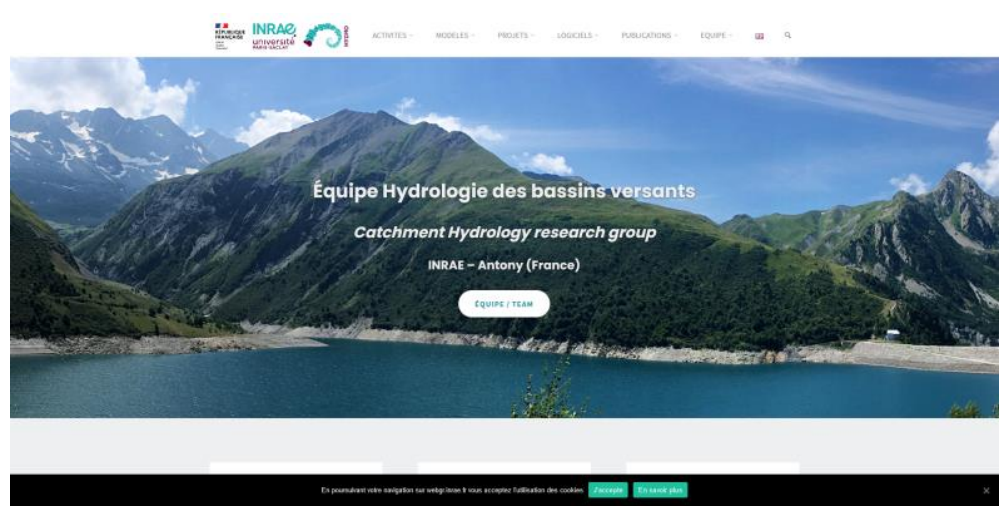

